Review

\title{
Overview on the Evolution of Laser Welding of Vascular and Nervous Tissues
}

\author{
Diogo Francisco Gomes ${ }^{1}\left(\mathbb{D}\right.$, Ivan Galvão ${ }^{1,2,3, *(\mathbb{D})}$ and Maria Amélia Ramos Loja 1,2,4,5 (D) \\ 1 ISEL, Department of Mechanical Engineering, Polytechnic Institute of Lisbon, 1959-007 Lisbon, Portugal; \\ A39343@alunos.isel.pt (D.F.G.); amelialoja@dem.isel.pt (M.A.R.L.) \\ 2 CIMOSM, ISEL, Polytechnic Institute of Lisbon, 1959-007 Lisbon, Portugal \\ 3 CEMMPRE, Department of Mechanical Engineering, University of Coimbra, 3030-788 Coimbra, Portugal \\ 4 IDMEC, Instituto Superior Técnico, Universidade de Lisboa, 1049-001 Lisbon, Portugal \\ 5 NOVA UNIDEMI, Faculty of Science and Technology, Universidade NOVA de Lisboa, \\ 2829-516 Caparica, Portugal \\ * Correspondence: ivan.galvao@dem.uc.pt
}

Received: 4 March 2019; Accepted: 22 May 2019; Published: 27 May 2019

check for updates

\begin{abstract}
Laser welding presents a core position in the health sector. This process has had an outstanding impact on the surgical procedures from many medical areas, such as on vascular and nervous surgeries. The aim of the present research is to present an overview on the evolution of laser welding of vascular and nervous tissues. These surgeries present many advantages, such as an absence of foreign-body reactions and aneurysms and good tensile strengths. However, despite the sutureless nature of the process, complementary sutures have been applied to support the procedure success. An important concern in vascular and nervous laser welding is the thermal damage. The development of temperature-controlled feedback systems has reduced this concern with a very precise control of the laser parameters. The bonding strength of vascular and nerve laser welds can be enhanced with the application of solder solutions, bonding materials, and laser-activated dyes. Alternative techniques to laser welding, such as photochemical tissue bonding and electrosurgical high-frequency technologies, have also been tested for vascular and nervous repairs.
\end{abstract}

Keywords: laser welding; vascular; nervous; tissue; thermal damage; solder

\section{Introduction}

Welding technologies are used all over the world in the production of diverse components for several sectors of activity. The demanding manufacturing strategies currently used in industry, which are focused on producing increasingly efficient components, must be supported by an ongoing optimization of the joining processes. Therefore, important research on welding technology is being conducted. As widely spread conventional fusion welding processes are no longer an effective solution for joining some materials and material combinations, the most explored research issue has been the optimization of nonconventional welding processes, such as friction stir welding [1,2], ultrasonic welding [3,4], diffusion welding [5,6], magnetic pulse welding [7,8], laser welding, etc. Laser welding presents excellent characteristics, specifically, its accuracy and high-power density, enabling the production of very localized welds, with minimal distortion and with a residual heat-affected zone. Therefore, laser welding of a large range of cutting-edge materials, such as NiTi shape memory alloys [9,10], Ni-based superalloys [11,12], and Ti alloys [13,14], and material combinations, such as Ta/Mo [15,16], NiTi/CuAlMn [17], NiTi/Ti [18], and Cu/Ti [19], has been intensively studied.

Welding technology is traditionally associated with industrial production. However, it is important to realize that the applications of welding, and especially laser welding, are not restricted to this 
field. This process has also presented a core position in the health sector [20-22]. The integration of laser welding in this sector has promoted a revolution in medical practices by enabling the development of safer, earlier, and faster surgical interventions and therapies $[23,24]$. Actually, medical parameters, such as post-operative pain, narcotics usage, tissue thermal response, and operation time, have been significantly improved [25,26]. Although laser welding in the health sector is not recent, it remains a research topic with extreme relevance and actuality, since improved equipment, procedures, and strategies have been developed in order to define optimized interventions that maximize the patient's health $[27,28]$. Significant research on laser-welding procedures has been conducted in a large range of medical areas, such as ophthalmology [29-31], gastroenterology [32,33], urology [34-36], and odontology [37-39].

Laser welding has also had an outstanding impact on nervous and vascular surgeries. These surgeries were some of those in which more outcomes were achieved by the integration of laser-welding technology. However, although important advances have been achieved in this field over the last 30 years, which have enabled laser welding to become a common practice in these surgeries, literature survey and review works on this issue are very incipient in literature. For this reason, the aim of the present research is to present an overview on the evolution of laser welding of vascular and nervous tissues. The fundaments of the process and the technological evolution registered in this field, concerning the equipment and the adopted procedures and strategies, were analyzed in this research.

\section{Laser Welding of Vascular and Nervous Tissues}

\subsection{Contextualization}

Different repair techniques can be applied to nerves, arteries, and veins. The success of these surgeries depends on several factors, such as the severity of the injury, the surgical technique, the surgeon's experience, and the post-operative biological response [40]. In the most common surgeries (arteriotomies, venotomies, arteriovenous fistulas, and nerve coaptations), the conventional repair procedure is based on sutures. However, as displayed in Table 1, besides the suture-based procedures, different reconstructive techniques, presenting improved operative and post-operative results, have been developed.

Table 1. Techniques for nerve, arteries, and veins repairs.

\begin{tabular}{|c|c|c|}
\hline \multicolumn{3}{|c|}{ Techniques for Nerve, Arteries, and Veins Repairs } \\
\hline \multirow{2}{*}{ Conventional techniques } & \multirow{2}{*}{ Suture } & Nonabsorbable suture [41-43] \\
\hline & & Absorbable suture [41] \\
\hline \multirow{8}{*}{ Nonconventional techniques } & \multirow{5}{*}{ Laser welding } & Argon laser welding $[41,44]$ \\
\hline & & $\mathrm{CO}_{2}$ laser welding [44-47] \\
\hline & & Nd:YAG laser welding [44] \\
\hline & & Infrared diode laser welding $[48,49]$ \\
\hline & & Potassium titanyl phosphate laser welding [50] \\
\hline & \multicolumn{2}{|c|}{ Laser welding with intraluminal light source [51] } \\
\hline & \multicolumn{2}{|c|}{ Photochemical tissue bonding $[40,52-54]$} \\
\hline & \multicolumn{2}{|c|}{ Electrosurgical high-frequency welding [55] } \\
\hline
\end{tabular}

Although the most conventional nonabsorbable sutures are reliable and relatively inexpensive, several studies have pointed to a direct relation between them and post-operative biological problems, such as foreign-body reactions, intimal hyperplasia, and anastomotic stenosis [40-42,45]. In order to minimize these problems, Lawrence et al. [41] compared the application of absorbable and 
nonabsorbable sutures. Although similar burst strengths were achieved, the absorbable sutures were found to present an excellent recovery of the blood vessel wall, with minimal inflammatory modifications. However, prior to this study, the medical evolution had already shown results towards a sutureless approach with the integration of laser in medical surgeries. Repair of blood vessels with Nd:YAG laser was achieved in 1979 [56] and, some years later, nerve coaptations by laser welding were successfully reported by White et al. [44,57]. The advantages of laser welding were evident: increased accuracy, decreased operative time, low foreign-body reactions, and a reduction in the formation of post-operative aneurysms. Despite these advantages, which have been corroborated by recent literature [58], many studies have emphasized the relevance of the surgical experience to achieve successful results $[41,45,50]$.

\subsection{Welding Procedure}

As shown in Figure 1, laser welding occurs when the laser energy induces photomechanical and photothermal tissue modifications, mainly due to its capability for selective modulation of the biologic functions of cells. According to various studies [59-61], the tissue remodeling process is characterized by the equilibrium between extracellular matrix (ECM) remodeling and collagen biosynthesis. This balance is achieved through the thermal response of three main biologic structures: matrix metalloproteinases (MMPs) [62,63], transforming growth factors (TGFs) [64,65], and heat-shock proteins (HSPs) [66,67]. When observing collagen biosynthesis, Nagata [67] and DeBruler et al. [68] showed that HSP 47 is responsible for producing neocollagenesis that will benefit tissue remodeling. In turn, Wang and Khalil [62] and Nesi-Reis et al. [69] stated that MMPs have an important role in vascular tissue remodeling, since their activation will act upon collagen degradation and ECM transformations. Additionally, positive results on collagen expression and an increased number of new growing vessels were recently reported by Fortuna et al. [70] through the application of the $670 \mathrm{~nm}$ GaAIAs laser.

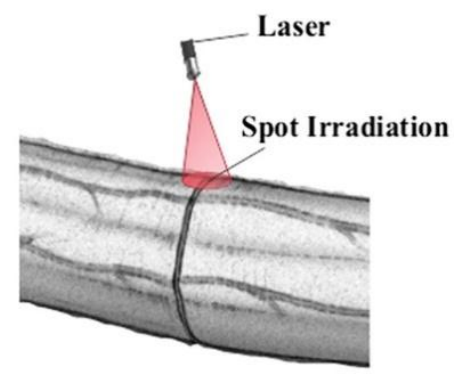

Figure 1. Schematics of laser welding of a nervous tissue [40].

Considering the ECM transformations and collagen biosynthesis, laser irradiation focuses on structural proteins, resulting in the protein denaturation process at temperatures between $60^{\circ} \mathrm{C}$ and $65^{\circ} \mathrm{C}[41,44,71,72]$. When the temperature exceeds $65^{\circ} \mathrm{C}$, the fusion with laser does not serve its purpose and cell degeneration takes place, primarily through vaporization at $100{ }^{\circ} \mathrm{C}$, and finally through burn or disruption at higher temperatures $[41,44,71,72]$. Thus, the optimization of the laser power and the exposure time is required to achieve the cross-linking fusion of the collagen fibrins, which is directly related to the success of the welding operation $[41,42,44,55]$.

Despite the precision and the efficiency of laser welding in vascular and nerve surgeries, thermal damage of the cells may occur, i.e., damage without possible regeneration, which results in a low tensile strength of the bonding area. Thermal tissue degeneration is directly related to laser parameters and biological conditions, mainly with the laser exposure time and the absorptive properties of the bonding region. Equilibrium of these factors is crucial to achieve improved results [47,49]. Moreover, it has been concluded that variables, such as the laser wavelength, the depth of tissue penetration, the energy fluency, and the use of cooling solutions, also influence the success of the surgery $[40,44,45]$. Several strategies have been tested in laser-welding procedures in order to minimize the thermal 
damage of the tissues, specifically, the use of thermal feedback systems, saline solutions, and different irradiation techniques.

The use of thermal feedback systems is a very effective strategy for preventing thermal damage, as they enable the monitoring of the temperature in the weld region, with a very precise control of the laser parameters [42,45,47,52,73]. Regarding the use of saline solutions, although Menosky et al. [45] reported that it could decrease the bonding strength of the weld, many other studies demonstrated that it had no implications on this property, being an effective strategy for cooling down the welding site $[41,42,57,71]$. Another strategy was tested by Pabittei et al. [72], who compared different irradiation techniques in vascular repairs, specifically, laser-welding scanning and single-spot laser welding. According to these authors, the single-spot method may be more beneficial when applied through multiple laser pulses in the surgical area, enabling tissue to cool down between pulses, and therefore, decreasing the thermal damage. Research has also been conducted to predict tissue damage and the corresponding effect by a finite element method, which may provide useful pre-operative information for the laser-welding procedure [74].

In laser welding of vascular and nervous tissues, it is also very important to consider the tissue apposition, i.e., the position of the adjacent tissues in which the welding procedure occurs, since it determines the quality of the bonding of the collagen fibrins $[45,71,73]$. In order to improve the welding conditions, traction sutures can be used to approximate the tissues, enabling higher bonding strengths to be achieved [42,47,57,71,73]. In turn, Nakadate et al. [48], in laser-assisted vessel repair (LAVR), reported the beneficial effect of preloaded longitudinal compression on the weld strength. These authors reported a success rate of $83 \%$ when compared to welds in which preloaded compression was absent. Figure 2 shows the instrumentation used by them, in which the vessel clamp device (Figure 2a) used for the application of the longitudinal compression in the pre-operative welding repair (Figure $2 b$ ) can be observed. Additionally, Table 2 summarizes results from previous works on vascular laser welding in which the use of complementary sutures was studied. Barton et al. [40] and Kramer and Rentschler [58] recently stated that many surgeons still use additional sutures as a complement to the laser-welding techniques.

(a)

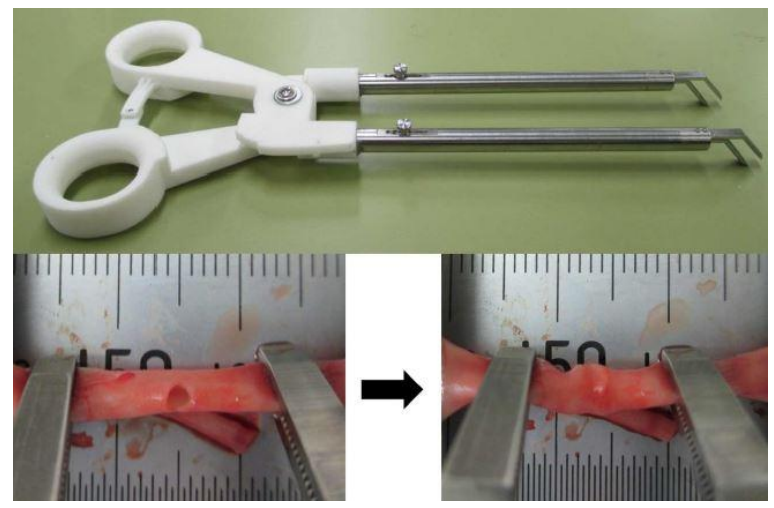

Vessel clamp device

reloading

procedure

Figure 2. Instrumentation for preloaded longitudinal compression: (a) Vessel clamp device (prototype); (b) Procedure of preloaded longitudinal compression [48].

Table 2. Laser welding with complementary sutures in vascular and nerve surgeries.

\begin{tabular}{cccc}
\hline Study & $\begin{array}{c}\text { Total No. } \\
\text { of Welds }\end{array}$ & $\begin{array}{c}\text { No. of Welds with } \\
\text { Complementary Sutures }\end{array}$ & $\begin{array}{c}\text { No. of Additional } \\
\text { Sutures Per Weld }\end{array}$ \\
\hline White et al. [44] & $5^{\text {a }}$ & 1 & 1 \\
White et al. [57] & 12 & 12 & 1 \\
White et al. [71] & 24 & 12 & 1 to 2 \\
Lawrence et al. [41] & 61 & 55 & 1 \\
Hasegawa et al. [42] & 12 & 8 & 1 to 3 \\
\hline \multicolumn{2}{c}{ a_only the welds produced with argon laser were considered. }
\end{tabular}


Another crucial aspect in vascular and nervous surgeries consists of the analysis of the end point of laser welding. The most conventional method is visual feedback. Chuck et al. [56] and Menosky et al. [45] created visual identification scores to correlate the different argon-laser parameters, and the resulting end points, with the response of the tissue. Figure 3 shows the stages of welded end points, with the "whitening" and the "beginning of caramelization" being the most adequate appearances $[45,47,56,73]$.

\begin{tabular}{c|c|c} 
Score & Visual identification \\
\hline 0 & Visible effect \\
1 & Dehydration/Vaporization \\
2 & Shrinkage & \\
\hline 3 & Whitening & Adequate laser \\
welding end point \\
\hline 5 & Caramelization \\
6 & Carbonization \\
\hline
\end{tabular}

Figure 3. Visual identification scores and adequate laser-welding end point $[45,56]$.

In addition to visual feedback, other methods have been developed to analyze the end point of laser welding. The most reported method consists of measuring the temperature using thermal feedback systems [42,45]. As reported above, these systems are also associated with the prevention of tissue weakening by thermal damage [51].

\subsection{Laser Technology}

According to literature, the most commonly used medical lasers are $\mathrm{CO}_{2}$, argon, and Nd:YAG. The $\mathrm{CO}_{2}$ and argon lasers are those with the most suitable application in medical surgeries due to their laser properties and their biological compatibility $[40,41,46,73]$. The application of these lasers is characterized by their coagulation, vaporization, and disruption capabilities [44]. Considering the published research on laser welding of vascular and nervous tissues, it is possible to define the most reported surgical application for each type of laser. The main applications, advantages, and drawbacks of $\mathrm{CO}_{2}$, argon, and Nd:YAG lasers are displayed in Table 3.

Table 3. Argon, $\mathrm{CO}_{2}$, and Nd:YAG characteristics in vascular and nerve laser-welding repairs.

\begin{tabular}{|c|c|c|c|}
\hline Laser & Suitable Surgeries & Advantages & Drawbacks \\
\hline Argon & Vascular repairs & $\begin{array}{c}\text { Deep vessel wall } \\
\text { penetration with lower } \\
\text { energy output [41] }\end{array}$ & $\begin{array}{l}\text { Nerve absorption of laser light is minimum due to } \\
\text { the lack of presence of significant chromophores [73] }\end{array}$ \\
\hline \multirow[b]{2}{*}{$\mathrm{CO}_{2}$} & Nerve repairs & High energy output [41] & Used primarily to cut and vaporize tissue [44] \\
\hline & & Low penetration depth [45] & $\begin{array}{l}\text { Low strength in arterial repairs, cannot sustain } \\
\text { systemic pressures [57] }\end{array}$ \\
\hline \multirow{3}{*}{ Nd:YAG } & \multirow{3}{*}{ Vascular repairs } & \multirow{3}{*}{$\begin{array}{l}\text { Easy penetration of the } \\
\text { tissue [44] }\end{array}$} & Limited to microvascular anastomoses surgeries [41] \\
\hline & & & $\begin{array}{l}\text { Produces deep uncontrolled thermal injury due to } \\
\text { excessive energy density [44] }\end{array}$ \\
\hline & & & $\begin{array}{l}\text { Low strength in arterial repairs, cannot sustain } \\
\text { systemic pressures [57] }\end{array}$ \\
\hline
\end{tabular}

An overview of the histological results of $\mathrm{CO}_{2}$ and argon repairs over conventional suturing is summarized in Table 4. Regarding the vascular argon laser-welding repairs, the results are superior when compared to conventional suture application. White et al. [44] reported that the biological effects 
of argon laser welding in vascular healing presented a minimal inflammatory response, near normal collagen content, and no aneurysm formation. The optimal vascular results of argon laser welding have been corroborated by other authors along the years [41,42,57,71]. Nervous $\mathrm{CO}_{2}$ laser-welding repairs also presented evolutionary results. Specifically, Bhatt et al. [50] concluded that $\mathrm{CO}_{2}$ laser-welded nerve coaptations can be performed with higher functional recovery rates than those achieved by nerve sutures. Additionally, Leclère et al. [75] and Nakadate et al. [48] showed that the use of infrared (IR) diode lasers can be excellent alternatives. At wavelengths of 1450, 1940 and $1950 \mathrm{~nm}$, water presents high absorption coefficients, which enables laser-welding repairs to be performed without additional materials, while still obtaining good surgical results, such as minimal aneurysm formation. Another alternative to $\mathrm{CO}_{2}$ and argon laser welding can be the potassium titanyl phosphate (KTP) laser-welding technique. According to Bhatt et al. [50], it has a better functional recovery than $\mathrm{CO}_{2}$ laser welding, i.e., $92.4 \%$ against $86.8 \%$.

Table 4. Overview of histological results of $\mathrm{CO}_{2}$ and argon repairs over conventional suturing.

\begin{tabular}{|c|c|c|c|}
\hline \multirow{2}{*}{ Study } & \multicolumn{2}{|c|}{ Laser Welding } & \multirow{2}{*}{ Histologic Examination } \\
\hline & $\mathrm{CO}_{2}$ & Argon & \\
\hline White et al. [44] & - & $\mathrm{x}$ & $\begin{array}{c}\text { Minimal inflammatory response, near normal collagen content, } \\
\text { absent of aneurysm formation }\end{array}$ \\
\hline White et al. [57] & - & $\mathrm{x}$ & $\begin{array}{l}\text { Absent of hematomas, false aneurysms or luminal dilatation, and } \\
\text { minimal inflammatory response }\end{array}$ \\
\hline White et al. [71] & - & $\mathrm{x}$ & Minimal inflammatory response and near-normal collagen content \\
\hline Lawrence et al. [41] & - & $\mathrm{x}$ & Absent aneurysm formation \\
\hline Menosky et al. [45] & $\mathrm{x}$ & - & Absent foreign body reaction, minimized scar tissue formation \\
\hline Happak et al. [46] & $\mathrm{x}$ & - & Minimized tissue thermal damage and no foreign body reactions \\
\hline Hasegawa et al. [42] & - & $\mathrm{x}$ & $\begin{array}{l}\text { Absent aneurysm formation although with no complete } \\
\text { regeneration of the elastic lamina }\end{array}$ \\
\hline Jonge et al. [47] & $\mathrm{x}$ & - & Minimal thermal necrosis and welding strength increase \\
\hline Bhatt et al. [50] & $\mathrm{x}$ & - & Good functional recovery with no nerve dehiscence \\
\hline
\end{tabular}

\subsection{Welding Parameters and Bonding Conditions}

An overview of the main researches conducted in vascular and nervous laser welding over the last 30 years is presented in Table 5. The laser type and the main parameters tested in these works are displayed in the table. The research has been mainly focused on optimizing the inverse relation existing between the laser power and the exposure time by testing different laser types (different wavelengths). Regarding the laser operation mode, continuous wave (CW) was used in most of the studies, although the laser was often performed as a sequence of consecutive pulses (not short-pulse laser mode) by the actuation of a switch device, like, for example, a foot switch. For this reason, the table presents the weld time, which corresponds to the total time per weld, the time of each pulse, and the interval between consecutive pulses. It should be noted that the tested conditions are not generalizable, since they strongly depend on the specific application, and consequently, on the interaction mechanisms between the laser radiation and the welded tissues. The application of external bonding materials, protein solutions (solders), and dyes in the weld region has also been intensively studied (Figure 4). 
Table 5. Chronological overview of laser-welding results in vascular and nerve repair.

\begin{tabular}{|c|c|c|c|c|c|c|c|c|}
\hline \multirow{2}{*}{ Study } & \multirow{2}{*}{ Surgery } & \multirow{2}{*}{ Laser Type } & \multirow{2}{*}{$\begin{array}{l}\text { Laser } \\
\text { Mode }\end{array}$} & \multicolumn{2}{|c|}{ Welding Parameters } & \multicolumn{3}{|c|}{ Time } \\
\hline & & & & $\begin{array}{c}\text { Wavelength } \\
\text { (nm) }\end{array}$ & $\begin{array}{c}\text { Power } \\
\text { (W) }\end{array}$ & $\begin{array}{c}\text { Weld } \\
\text { Time (s) }\end{array}$ & $\begin{array}{c}\text { Pulse } \\
\text { Time (s) }\end{array}$ & $\begin{array}{c}\text { Pulse } \\
\text { Interval (s) }\end{array}$ \\
\hline \multirow{3}{*}{ White et al. [44] } & \multirow{3}{*}{ Vascular } & Argon & CW & $458-515$ & 1.5 & $300-400$ & NR & NR \\
\hline & & $\mathrm{CO}_{2}$ & $\mathrm{CW}$ & 10,600 & $1-2$ & $20-40$ & NR & NR \\
\hline & & Nd:YAG & $\mathrm{CW}$ & 1060 & 7 & $20-25$ & NR & NR \\
\hline White et al. [57] & Vascular & Argon & CW & NR & 0.5 & 240 & 5 & 0.2 \\
\hline White et al. [71] & Vascular & Argon & $\mathrm{CW}$ & NR & 0.5 & $125-150$ & 5 & 0.2 \\
\hline Chuck et al. [56] & Vascular & Argon & $\mathrm{CW}$ & 488 & $0.01-0.05$ & $15-120$ & NR & NR \\
\hline Lawrence et al. [41] & Vascular & Argon & $\mathrm{CW}$ & NR & 0.75 & 100 & 5 & 0.2 \\
\hline Menosky et al. [45] & Nerve & $\mathrm{CO}_{2}$ & $\mathrm{CW}$ & NR & $0.05-0.15$ & NR & $0.1-3$ & NR \\
\hline Curtis et al. [43] & Nerve & IR diode & $\mathrm{CW}$ & 810 & 0.08 & NR & NR & NR \\
\hline Happak et al. [46] & Nerve & $\begin{array}{l}\mathrm{CO}_{2} \text { with } \\
\text { power } \\
\text { reduction unit }\end{array}$ & $\mathrm{CW}$ & NR & 0.06 & NR & NR & NR \\
\hline Hasegawa et al. [42] & Vascular & Argon & $\mathrm{CW}$ & NR & 0.17 & NR & 5 & NR \\
\hline Stewart et al. [76] & Vascular & IR diode & $\mathrm{CW}$ & 808 & 0.08 & $4 \times 0.5$ & NR & NR \\
\hline \multirow{2}{*}{ Ott et al. [51] } & \multirow{2}{*}{ Vascular } & \multirow{2}{*}{ IR diode } & \multirow{2}{*}{$\mathrm{CW}$} & \multirow{2}{*}{808} & 0.41 & 30 & \multirow{2}{*}{ NR } & \multirow{2}{*}{ NR } \\
\hline & & & & & 0.55 & 45 & & \\
\hline O'Neill et al. [52] & Vascular & $\begin{array}{l}\text { PTB with } \\
\text { Nd:YAG }\end{array}$ & $\mathrm{CW}$ & 532 & 0.35 & $2 \times 30$ & NR & NR \\
\hline Jonge et al. [47] & Vascular & $\mathrm{CO}_{2}$ & $\mathrm{CW}$ & 10,600 & 0.17 & $261 \pm 40$ & NR & NR \\
\hline Bogni et al. [77] & Vascular & IR diode & CW & 808 & $0.4-3$ & $2.5-30$ & NR & NR \\
\hline \multirow{2}{*}{ Pabittei et al. [72] } & \multirow{2}{*}{ Vascular } & $\begin{array}{c}\text { IR diode } \\
\text { single-spot }\end{array}$ & \multirow{2}{*}{$\mathrm{CW}$} & \multirow{2}{*}{670} & \multirow{2}{*}{1.6} & 50 & NR & NR \\
\hline & & $\begin{array}{l}\text { IR diode } \\
\text { scanning }\end{array}$ & & & & 82 & NR & NR \\
\hline Pabittei et al. [49] & Vascular & IR diode & CW & 670 & 0.096 & NR & 25 & NR \\
\hline Nakadate et al. [48] & Vascular & IR diode & $\mathrm{CW}$ & 970 & 2.4 & 30 & NR & NR \\
\hline \multirow{2}{*}{ Bhatt et al. [50] } & \multirow{2}{*}{ Vascular } & $\mathrm{CO}_{2}$ & $\mathrm{CW}$ & 10,600 & 0.1 & NR & 1 & NR \\
\hline & & KTP & $\mathrm{CW}$ & 532 & $3-4$ & NR & 1 & NR \\
\hline Hiebl et al. [78] & Vascular & IR diode & $\mathrm{CW}$ & 808 & $0.25-1.5$ & 30 & NR & NR \\
\hline
\end{tabular}
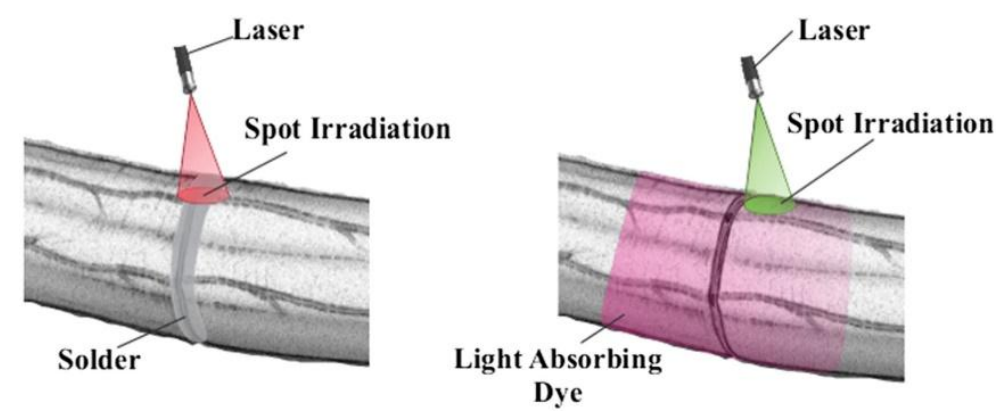

Figure 4. Schematics of laser welding of a nervous tissue, with the application of a solder and a light absorbing dye [40].

The materials referred to above improve the technical parameters and reduce the thermal damage, enabling the achievement of higher weld strength [43,46,72,76]. Menosky et al. [45] concluded that the amount and concentration of structural proteins is directly correlated with the bonding strength of the welded repair. This correlation has been recently corroborated by Hiebl et al. [78]. The different types of bonding materials and solders reported to be used in nervous and vascular repairs are displayed in Table 6. Although the biodegradable glues (fibrin and cyanoacrylate glues and polyethylene glycol) 
have initially been used with success, due to reduced inflammatory reactions and easy application, they should be avoided because of their rigidity, cytotoxicity, and risk of infection $[40,51,58]$. Moreover, the development of albumin-based solution solders allowed higher biocompatibility between its proteinaceous structure and collagen fibers. As its application is possible with different variations in composition, this solder solution is the most common in these procedures $[40,46,72,76]$. For example, BioGlue, which is composed of $45 \%$ bovine serum albumin and $10 \%$ glutaraldehyde, cross-links with tissue fibers through chemical bindings, allowing vascular chemical stabilization of sutured and welded sites [58].

Table 6. Advantages and drawbacks of solders and bonding materials used in vascular and nerve repairs.

\begin{tabular}{ccc}
\hline Bonding Materials and Solders & Advantages & Drawbacks \\
\hline Fibrin glue [40] & $\begin{array}{c}\text { Reduces inflammatory tissues and } \\
\text { easy application }\end{array}$ & Low tensile strength, infection risk \\
\hline Cyanoacrylate glue [40,58] & $\begin{array}{c}\text { High tensile strength } \\
\text { and easy application }\end{array}$ & $\begin{array}{c}\text { Requires support stay sutures, causes } \\
\text { fibrosis, foreign-body toxicity }\end{array}$ \\
\hline Polyethylene glycol (PEG) $[40]$ & $\begin{array}{c}\text { Nontoxic, biocompatible } \\
\text { and reduces scar tissue }\end{array}$ & $\begin{array}{c}\text { Slow degradation process } \\
\text { (over 20 months) }\end{array}$ \\
\hline Albumin-based solution $[40,47,78]$ & $\begin{array}{c}\text { In nerve repairs, protects the } \\
\text { epineurium, increases bonding } \\
\text { strength, reduces thermal damage }\end{array}$ & $\begin{array}{c}\text { Leakage of fluid solder, thermal } \\
\text { damage still present, viral infection } \\
\text { risk, becomes brittle }\end{array}$ \\
\hline
\end{tabular}

Important research has been conducted in the application of solder solutions in vascular and nerve tissue welding. Menosky et al. [45] compared different types of solders in laser nerve welding. They observed an increased bonding strength with dried albumin, $20 \%$ albumin and egg white solutions, when compared to welding alone and to welding with fibrin-glue repairs. No improvement in bonding strength was achieved with an application of a 5\% albumin solution. In turn, Curtis et al. [43] reported that leakage of liquid solder solutions occurred during surgery, creating an obstacle to the regeneration process. In agreement with this, Jonge et al. [47] observed that the disruption of low-viscosity solder solutions occurred at the solder midline. However, regarding semi-solid solder solutions, the same authors reported that these solutions withstand higher pressures in the solder area than at the interface, due to higher protein concentrations. The application of a semi-solid solder solution in arterial laser welding is illustrated in Figure 5. As illustrated by the black dots, although laser welding is a highly localized process, a heat-affected zone (HAZ) was generated around the welding site, which agrees well with the aforementioned concerns regarding thermal damage.

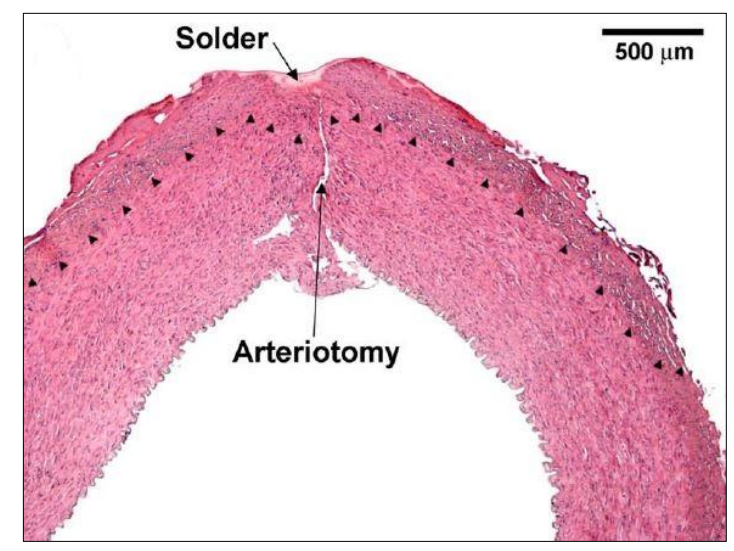

Figure 5. Transverse cross-section of an artery repaired by laser welding, with the application of a semi-solid solder solution [47]. 
Bogni et al. [77] and Pabittei et al. [72] focused their works on minimizing solder leakage by using biodegradable polymers as carrier material for the liquid solders and by studying solder viscosity, respectively. In agreement with the previous researches, Pabittei et al. [49] reported that the application of semi-solid solders provides higher protein density and cohesive bonding when compared to fluid solders. The authors also reported that porous polymer scaffolds can be used to prevent solder leakage. In turn, Barton et al. [40] confirmed the possibility of including support cross-linking agents, such as genipin, in albumin-based solutions to improve their flexibility and reduce brittleness. The improvement of solder properties by adding other elements had already been tested some years earlier by Stewart et al. [76], who introduced heparin in an albumin-based solder with the purpose of reducing microvessel thromboses. More recently, Hiebl et al. [78] reported the effectiveness of using carrier membranes with bovine serum albumin (BSA) solder linked by covalent cross-linking bindings and indocyanine green (ICG) dye to improve bonding strength and to prevent liquid solder leakage. In fact, the addition of laser-activated dyes in solder solutions (ICG and fluorescein isothiacyanate), enabling the use of lower energy outputs due to selective laser absorption, which minimizes the associated thermal damage, had already been reported in previous works, such as Chuck et al. [56], Curtis et al. [43], and Ott et al. [51].

Besides the welding parameters and the use of solder solutions, the welding process is also influenced by other issues. Specifically, handling laser welding in three-dimensional (3D) approaches requires specific surgical skills due to the necessary manipulation of the vascular and nervous elements, which may lead to injury aggravation and procedure repetition [50,51]. To avoid manual surgical manipulation in the laser-welding procedure, Ott et al. [51] presented a different surgical approach, which is shown in Figure 6. This strategy consists of the insertion of a laser fiber implemented in a balloon catheter, allowing a $360^{\circ}$ laser irradiation over a two-layer soldering procedure. Eleven successful welds in fourteen executed were reported by these authors. In turn, Pabittei et al. [49] also reported that a laser fiber that delivers a $360^{\circ}$ laser irradiation can also diminish the thermal damage.

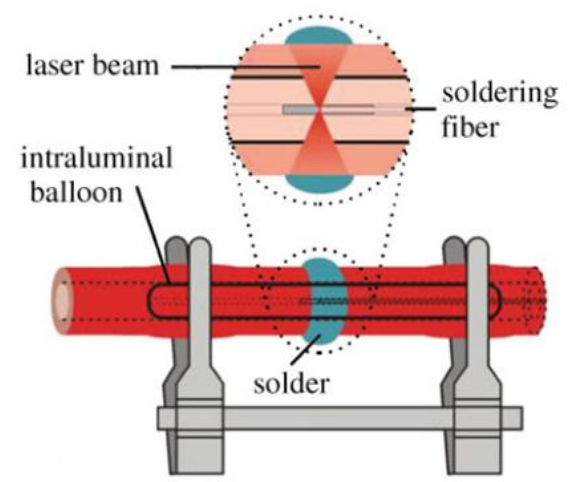

Figure 6. Schematics of the laser-assisted vessel soldering [51].

As described above, important progress has been registered in laser welding of nervous and vascular tissues. Therefore, the development of fiber lasers is of great importance to the laser-welding technique, mostly due to their advantages, such as excellent heat dissipation, beam quality, and efficiency $[79,80]$. Because of their diversified operating modes, wavelengths, and energy levels, different fiber lasers, such as erbium-, thulium-, holmium-, and ytterbium-doped families, can be used, for example, in microsurgeries of soft tissues [80,81]. The effect of these lasers in soft tissues can range from ablative purposes to regenerative procedures like laser welding [82]. In terms of medical applications, various studies have proven their suitability for photodynamic therapies, biomedical sensing, as well as for other procedures in the vascular and dentistry fields $[81,83,84]$.

Although laser-welding improvements have been achieved with solder solutions, laser-activated dyes, intraluminal devices with $360^{\circ}$ laser irradiation, etc., inherent thermal damage is still present. As an alternative to thermal laser welding, photochemical tissue bonding (PTB) does not inflict any thermal 
damage to the welded and surrounding tissues. With this technique, sealing of tissue is achieved through the use of dyes that are chemically activated, such as Rose Bengal (RB) dye and Riboflavin-5-Phosphate, allowing the formation of fiber cross-linking bindings [53,54]. Results showed no operative and post-operative bleeding, absence of aneurysms, and high tensile strength $[40,49,52,54,58]$. Moreover, electrosurgical high-frequency (ESHF) technology has already been tested as an alternative technique to laser photothermal and photochemical mechanisms. Korsak and Chaikovskii [55] presented an animal study in which peripheral nerve repairs were made by welding soft tissues with high-frequency current. A similar morphology was achieved in sutured and high-frequency (HF)-welded nerves, with beneficial effects of ESHF welding in terms of the regeneration process.

It should also be noted that new research directions are starting to emerge within these surgical practices. Auxiliary technological devices and instrumentation, such as robotic-assisted surgeries with enhanced image-processing systems [85-87], as well as the development of new biomaterials based on nanotechnology $[88,89]$, show a great potential for driving the future evolution of reconstructive vascular and nervous laser welding.

\section{Conclusions}

An overview on the evolution of vascular and nervous surgeries by laser welding was presented in this research. The fundaments of the process and the technological evolution registered in this field were analyzed. The following conclusions can be drawn:

- Although laser welding presents many advantages, such as increased accuracy, decreased operative time, reduction of foreign-body reactions, and reduction of aneurysms formation, an accurate control of several process variables is required. The laser type and parameters, the exposure time, the tissue apposition, the temperature, and the absorptive conditions present high relevance.

- Thermal damage may occur in vascular and nervous laser welding. Different strategies have been tested to overcome this concern. Temperature-controlled feedback systems present the advantage of reducing the thermal damage with a very precise control of the laser parameters.

- The bonding strength of vascular and nerve welds can be enhanced with the application of solder solutions, bonding materials, and laser-activated dyes. The use of dyes with albumin-based solution solders has presented an especially beneficial effect on the welding conditions.

- Alternative techniques to thermal laser welding, such as photochemical tissue bonding and electrosurgical high-frequency technologies, have been tested for vascular and nervous repairs.

Author Contributions: Conceptualization, D.F.G., I.G., M.A.R.L.; methodology, D.F.G., I.G., M.A.R.L.; formal analysis, D.F.G., I.G., M.A.R.L.; investigation, D.F.G., I.G., M.A.R.L.; writing一original draft preparation, D.F.G.; writing一review and editing, D.F.G., I.G., M.A.R.L.; supervision, I.G., M.A.R.L.

Funding: This research received no external funding.

Acknowledgments: The authors acknowledge the support of ISEL-Polytechnic Institute of Lisbon, CIMOSM, CEMMPRE, IDMEC, and NOVA UNIDEMI. The third author also acknowledges the support of FCT through IDMEC, LAETA, project UID/EMS/50022/2019.

Conflicts of Interest: The authors declare no conflict of interest.

\section{References}

1. Costa, A.M.S.; Oliveira, J.P.; Pereira, V.F.; Nunes, C.A.; Ramirez, A.J.; Tschiptschin, A.P. Ni-Based Mar-M247 Superalloy as a Friction Stir Processing Tool. J. Mater. Process. Technol. 2018, 262, 605-614. [CrossRef]

2. Liu, F.C.; Hovanski, Y.; Miles, M.P.; Sorensen, C.D.; Nelson, T.W. A Review of Friction Stir Welding of Steels: Tool, Material Flow, Microstructure, and Properties. J. Mater. Sci. Technol. 2018, 34, 39-57. [CrossRef]

3. Jedrasiak, P.; Shercliff, H.R. Finite Element Analysis of Heat Generation in Dissimilar Alloy Ultrasonic Welding. Mater. Des. 2018, 158, 184-197. [CrossRef]

4. Goto, K.; Imai, K.; Arai, M.; Ishikawa, T. Shear and Tensile Joint Strengths of Carbon Fiber-Reinforced Thermoplastics Using Ultrasonic Welding. Compos. Part A Appl. Sci. Manuf. 2019, 116, 126-137. [CrossRef] 
5. Assari, A.H.; Eghbali, B. Solid State Diffusion Bonding Characteristics at the Interfaces of Ti and Al Layers. J. Alloys Compd. 2019, 773, 50-58. [CrossRef]

6. Varmazyar, J.; Khodaei, M. Diffusion Bonding of Aluminum-Magnesium Using Cold Rolled Copper Interlayer. J. Alloys Compd. 2019, 773, 838-843. [CrossRef]

7. Lueg-Althoff, J.; Bellmann, J.; Gies, S.; Schulze, S.; Tekkaya, A.E.; Beyer, E. Influence of the Flyer Kinetics on Magnetic Pulse Welding of Tubes. J. Mater. Process. Technol. 2018, 262, 189-203. [CrossRef]

8. Cui, J.; Li, Y.; Liu, Q.; Zhang, X.; Xu, Z.; Li, G. Joining of Tubular Carbon Fiber-Reinforced Plastic/Aluminum by Magnetic Pulse Welding. J. Mater. Process. Technol. 2019, 264, 273-282. [CrossRef]

9. Mehrpouya, M.; Gisario, A.; Brotzu, A.; Natali, S. Laser Welding of NiTi Shape Memory Sheets Using a Diode Laser. Opt. Laser Technol. 2018, 108, 142-149. [CrossRef]

10. Yao, R.; Dong, P.; Liaw, P.K.; Zhou, J.; Wang, W. Microstructure and Shape Memory Effect of Laser Welded Nitinol Wires. Mater. Lett. 2019, 238, 1-5. [CrossRef]

11. Rezaei, M.-A.; Naffakh-Moosavy, H. The Effect of Pre-Cold Treatment on Microstructure, Weldability and Mechanical Properties in Laser Welding of Superalloys. J. Manuf. Process. 2018, 34, 339-348. [CrossRef]

12. Hu, X.; Xue, Z.; Zhao, G.; Yun, J.; Shi, D.; Yang, X. Laser Welding of a Selective Laser Melted Ni-Base Superalloy: Microstructure and High Temperature Mechanical Property. Mater. Sci. Eng. A 2019, 745, 335-345. [CrossRef]

13. Yu, H.; Li, F.; Yang, J.; Shao, J.; Wang, Z.; Zeng, X. Investigation on Laser Welding of Selective Laser Melted Ti-6Al-4V Parts: Weldability, Microstructure and Mechanical Properties. Mater. Sci. Eng. A 2018, 712, $20-27$. [CrossRef]

14. Sun, Y.Y.; Wang, P.; Lu, S.L.; Li, L.Q.; Nai, M.L.S.; Wei, J. Laser Welding of Electron Beam Melted Ti-6Al-4V to Wrought Ti-6Al-4V: Effect of Welding Angle on Microstructure and Mechanical Properties. J. Alloys Compd. 2018, 782, 967-972. [CrossRef]

15. Zhou, X.; Huang, Y.; Hao, K.; Chen, Y. Cracking in Dissimilar Laser Welding of Tantalum to Molybdenum. Opt. Laser Technol. 2018, 102, 54-59. [CrossRef]

16. Zhou, X.; Huang, Y.; Chen, Y.; Peng, P. Laser Joining of Mo and Ta Sheets with Ti6Al4V or Ni Filler. Opt. Laser Technol. 2018, 106, 487-494. [CrossRef]

17. Oliveira, J.P.; Zeng, Z.; Andrei, C.; Braz Fernandes, F.M.; Miranda, R.M.; Ramirez, A.J.; Omori, T.; Zhou, N. Dissimilar Laser Welding of Superelastic NiTi and CuAlMn Shape Memory Alloys. Mater. Des. 2017, 128, 166-175. [CrossRef]

18. Shojaei Zoeram, A.; Akbari Mousavi, S.A.A. Laser Welding of Ti-6Al-4V to Nitinol. Mater. Des. 2014, 61, 185-190. [CrossRef]

19. Zhao, Y.; Wang, W.; Yan, K.; Liu, C.; Zou, J. Microstructure and Properties of Cu/Ti Laser Welded Joints. J. Mater. Process. Technol. 2018, 257, 244-249. [CrossRef]

20. Bass, L.S.; Treat, M.R. Laser Tissue Welding: A Comprehensive Review of Current and Future. Lasers Surg. Med. 1995, 17, 315-349. [CrossRef]

21. Pini, R.; Menabuoni, L.; Starnotti, L. First Application of Laser Welding in Clinical Transplantation of the Cornea. In Lasers in Surgery: Advanced Characterization, Therapeutics and Systems XI; Anderson, R.R., Bartels, K.E., Bass, L.S., Garrett, C.G., Gregory, K.W., Katzir, A., Kollias, N., Lucroy, M.D., Malek, R.S., Nelson, J.S., et al., Eds.; International Society for Optics and Photonics: Bellingham, WA, USA, 2001; Volume 4244, pp. 266-272. [CrossRef]

22. Rossi, F.; Matteini, P.; Ratto, F.; Menabuoni, L.; Lenzetti, I.; Pini, R. Laser Tissue Welding in Ophthalmic Surgery. J. Biophotonics 2008, 1, 331-342. [CrossRef]

23. Yilmaz, M.; Duzlu, M.; Catli, T.; Ustun, S.; Ceylan, A. Thermal Welding versus Cold Knife Tonsillectomy: A Prospective Randomized Study. Kaohsiung J. Med. Sci. 2012, 28, 270-272. [CrossRef] [PubMed]

24. Bouzari, N.; Elsaie, M.L.; Nouri, K. Laser and Light for Wound Healing Stimulation. In Lasers in Dermatology and Medicine; Springer: London, UK, 2011; pp. 267-275. [CrossRef]

25. Fida, A.R.; Sendi, K.S. Assessment of Postoperative Pain Scores in Thermal Welding and Conventional Tonsillectomy Techniques: A Randomized Control Study. Egypt. J. Ear Nose Throat Allied Sci. 2013, 14, 107-111. [CrossRef]

26. Canovetti, A.; Malandrini, A.; Lenzetti, I.; Rossi, F.; Pini, R.; Menabuoni, L. Laser-Assisted Penetrating Keratoplasty: 1-Year Results in Patients Using a Laser-Welded Anvil-Profiled Graft. Am. J. Ophthalmol. 2014, 158, 664-670.e2. [CrossRef] [PubMed] 
27. Matteini, P.; Rossi, F.; Ratto, F.; Pini, R. Laser Welding of Biological Tissue: Mechanisms, Applications and Perspectives. In Laser Imaging and Manipulation in Cell Biology; Pavone, F.S., Ed.; WILEY-VCH Verlag GmbH \& Co. KGaA: Weinheim, Germany, 2010; pp. 203-231.

28. Gerasimenko, A.Y.; Ichkitidze, L.P.; Pavlov, A.A.; Piyankov, E.S.; Ryabkin, D.I.; Savelyev, M.S.; Selishchev, S.V.; Rimshan, I.B.; Zhurbina, N.N.; Podgaetskii, V.M. Laser System with Adaptive Thermal Stabilization for Welding of Biological Tissues. Biomed. Eng. 2016, 49, 344-348. [CrossRef]

29. Tal, K.; Strassmann, E.; Loya, N.; Ravid, A.; Kariv, N.; Weinberger, D.; Katzir, A.; Gaton, D.D. Corneal Cut Closure Using Temperature-Controlled $\mathrm{CO}_{2}$ Laser Soldering System. Lasers Med. Sci. 2015, 30, 1367-1371. [CrossRef]

30. Menabuoni, L.; Malandrini, A.; Canovetti, A.; Lenzetti, I.; Pini, R.; Rossi, F. The Use of Femtosecond Laser and Corneal Welding in the Surgery of Keratoconus. In Icarus; Springer International Publishing: Cham, Switzerland, 2017; Volume 216, pp. 289-295. [CrossRef]

31. Heriot, W.J. Thermofusion of the Retina with the RPE to Seal Tears during Retinal Detachment Repair. Graefe's Arch. Clin. Exp. Ophthalmol. 2016, 254, 691-696. [CrossRef] [PubMed]

32. Zhao, L.; Song, C.; Wang, Z. Novel Concave-Convex Electrode for Colonic Anastomoses by Radiofrequency Thermo-Fusion. Surg. Endosc. 2015, 1809-1816. [CrossRef] [PubMed]

33. Papaspyrou, G.; Linxweiler, M.; Knöbber, D.; Schick, B.; Al Kadah, B. Laser $\mathrm{CO}_{2}$ Tonsillotomy versus Argon Plasma Coagulation (APC) Tonsillotomy: A Retrospective Study with 10-Year Follow-Up. Int. J. Pediatr. Otorhinolaryngol. 2017, 92, 56-60. [CrossRef]

34. Lee, C.A.; Kessler, C.M.; Varon, D.; Martinowitz, U.; Heim, M.; POPPAS, D.P.; SCHERR, D.S. Laser Tissue Welding: A Urological Surgeon's Perspective. Haemophilia 1998, 4, 456-462. [CrossRef]

35. Ninan, N.; Thomas, S.; Grohens, Y. Wound Healing in Urology. Adv. Drug Deliv. Rev. 2015, 82-83, 93-105. [CrossRef]

36. Amiel, G.; Shu, T.; Wadia, Y. MP23-19 Sutureless partial nephrectomy using laser tissue welding. J. Urol. 2016, 195, e269. [CrossRef]

37. Bertrand, C.; Poulon-Quintin, A. Proposals for Optimization of Laser Welding in Prosthetic Dentistry. J. Prosthodont. 2010, 19, 69-76. [CrossRef]

38. Yamashita, Y.; Yamaguchi, Y.; Noguchi, N.; Goto, M. Mandibular Reconstruction Using a Titanium Mesh Sheet Processed by Laser Welding after Segmental Mandibulectomy for Implant Placement. J. Oral Maxillofac. Surg. Med. Pathol. 2014, 26, 511-514. [CrossRef]

39. Paek, J.; Ahn, H.; Jeong, D.; Shim, J.; Kim, S.; Chung, K. Application of the 2-Piece Orthodontic C-Implant for Provisional Restoration with Laser Welded Customized Coping: A Case Report. Head Face Med. 2015, $11,7$. [CrossRef] [PubMed]

40. Barton, M.J.; Morley, J.W.; Stoodley, M.A.; Lauto, A.; Mahns, D.A. Nerve Repair: Toward a Sutureless Approach. Neurosurg. Rev. 2014, 37, 585-595. [CrossRef]

41. Lawrence, P.F.; Li, K.; Merrell, S.W.; Goodman, G.R. A Comparison of Absorbable Suture and Argon Laser Welding for Lateral Repair of Arteries. J. Vasc. Surg. 1991, 14, 183-189. [CrossRef]

42. Hasegawa, M.; Sakurai, T.; Matsushita, M.; Nishikimi, N.; Nimura, Y.; Kobayashi, M. Comparison of Argon-Laser Welded and Sutured Repair of Inferior Vena Cava in a Canine Model. Lasers Surg. Med. 2001, 29, 62-69. [CrossRef]

43. Curtis, N.J.; Lauto, A.; Trickett, R.; Owen, E.; Walker, D.M. Preliminary Study of Microsurgical Repairs of the Inferior Alveolar Nerve in Rats Using Primary Suturing and Laser Weld Techniques. Int. J. Oral Maxillofac. Surg. 1998, 27, 476-481. [CrossRef]

44. White, R.A.; Patrick Abergel, R.; Lyons, R.; Klein, S.R.; Kopchok, G.; Dwyer, R.M.; Uitto, J. Biological Effects of Laser Welding on Vascular Healing. Lasers Surg. Med. 1986, 6, 137-141. [CrossRef]

45. Menovsky, T.; Beek, J.F.; van Gemert, M.J.C. $\mathrm{CO}_{2}$ Laser Nerve Welding: Optimal Laser Parameters and the Use of Solders in Vitro. Microsurgery 1994, 15, 44-51. [CrossRef]

46. Happak, W.; Neumayer, C.; Holak, G.; Kuzbari, R.; Burggasser, G.; Gruber, H. Morphometric and Functional Results after $\mathrm{CO}_{2}$ Laser Welding of Nerve Coaptations. Lasers Surg. Med. 2000, 27, 66-72. [CrossRef]

47. Wolf-de Jonge, I.C.D.Y.M.; Heger, M.; van Marle, J.; Balm, R.; Beek, J.F. Suture-Free Laser-Assisted Vessel Repair Using $\mathrm{CO}_{2}$ Laser and Liquid Albumin Solder. J. Biomed. Opt. 2008, 13, 1-9. [CrossRef]

48. Nakadate, R.; Omori, S.; Ikeda, T.; Akahoshi, T.; Oguri, S.; Arata, J.; Onogi, S.; Hashizume, M. Improving the Strength of Sutureless Laser-Assisted Vessel Repair Using Preloaded Longitudinal Compression on Tissue Edge. Lasers Surg. Med. 2017, 49, 533-538. [CrossRef] 
49. Pabittei, D.R.; Heger, M.; Van Tuijl, S.; Simonet, M. Ex Vivo Proof-of-Concept of End-to-End Scaffold-Enhanced Laser-Assisted Vascular Anastomosis of Porcine Arteries. J. Vasc. Surg. 2015, 62, 200-209. [CrossRef] [PubMed]

50. Bhatt, N.K.; Mejias, C.; Kallogjeri, D.; Gale, D.C.; Park, A.M.; Paniello, R.C. Potassium Titanyl Phosphate Laser Welding Following Complete Nerve Transection. Laryngoscope 2017, 127, 1525-1530. [CrossRef]

51. Ott, B.; Constantinescu, M.A.; Erni, D.; Banic, A.; Schaffner, T.; Frenz, M. Intraluminal Laser Light Source and External Solder: In Vivo Evaluation of a New Technique for Microvascular Anastomosis. Lasers Surg. Med. 2004, 35, 312-316. [CrossRef] [PubMed]

52. O'Neill, A.C.; Winograd, J.M.; Zeballos, J.L.; Johnson, T.S.; Randolph, M.A.; Bujold, K.E.; Kochevar, I.E.; Redmond, R.W. Microvascular Anastomosis Using a Photochemical Tissue Bonding Technique. Lasers Surg. Med. 2007, 39, 716-722. [CrossRef]

53. Barton, M.; Piller, S.C.; Mahns, D.A.; Morley, J.W.; Mawad, D.; Longo, L.; Lauto, A. In Vitro Cell Compatibility Study of Rose Bengal-Chitosan Adhesives. Lasers Surg. Med. 2012, 44, 762-768. [CrossRef]

54. Ark, M.; Cosman, P.H.; Boughton, P.; Dunstan, C.R. Review: Photochemical Tissue Bonding (PTB) Methods for Sutureless Tissue Adhesion. Int. J. Adhes. Adhes. 2016, 71, 87-98. [CrossRef]

55. Korsak, A.V.; Chaikovskii, Y.B. Immunohistochemical Analysis of the Structure of Injured Peripheral Nerve Neuroma after Electrosurgical Welding Intervention. Bull. Exp. Biol. Med. 2015, 159, 789-791. [CrossRef] [PubMed]

56. Chuck, R.S.; Oz, M.C.; Delohery, T.M.; Johnson, J.P.; Bass, L.S.; Nowygrod, R.; Treat, M.R. Dye-Enhanced Laser Tissue Welding. Lasers Surg. Med. 1989, 9, 471-477. [CrossRef] [PubMed]

57. White, R.A.; Kopchok, G.; Donayre, C.; Lyons, R.; White, G.; Klein, S.R.; Pizzurro, D.; Abergel, R.P.; Dwyer, R.M.; Uitto, J. Large Vessel Sealing with the Argon Laser. Lasers Surg. Med. 1987, 7, 229-235. [CrossRef]

58. Kramer, E.A.; Rentschler, M.E. Energy-Based Tissue Fusion for Sutureless Closure: Applications, Mechanisms, and Potential for Functional Recovery. Annu. Rev. Biomed. Eng. 2018, 20, 1-20. [CrossRef]

59. Alam, M.; Hsu, T.-S.; Dover, J.S.; Wrone, D.A.; Arndt, K.A. Nonablative Laser and Light Treatments: Histology and Tissue Effects? A Review. Lasers Surg. Med. 2003, 33, 30-39. [CrossRef]

60. Liu, H.; Dang, Y.; Wang, Z.; Chai, X.; Ren, Q. Laser Induced Collagen Remodeling: A Comparative Study in Vivo on Mouse Model. Lasers Surg. Med. 2008, 40, 13-19. [CrossRef]

61. Bodendorf, M.O.; Willenberg, A.; Anderegg, U.; Grunewald, S.; Simon, J.C.; Paasch, U. Connective Tissue Response to Fractionated Thermo-Ablative Erbium: YAG Skin Laser Treatment. Int. J. Cosmet. Sci. 2010, 32, 435-445. [CrossRef]

62. Wang, X.; Khalil, R.A. Matrix Metalloproteinases, Vascular Remodeling, and Vascular Disease. In Advances in Pharmacology; Elsevier Inc.: Amsterdam, The Netherlands, 2018; Volume 81, pp. 241-330. [CrossRef]

63. Kono, A.; Oguri, A.; Yokoo, K.; Watanabe, H. YAG Laser Treatment Causes Rapid Degeneration and Regeneration of Collagen Fibres in Pig Skin and Facilitates Fibroblast Growth. J. Plast. Surg. Hand Surg. 2012, 46, 308-312. [CrossRef] [PubMed]

64. Lucke, L.D.; Bortolazzo, F.O.; Theodoro, V.; Fujii, L.; Bombeiro, A.L.; Felonato, M.; Dalia, R.A.; Carneiro, G.D.; Cartarozzi, L.P.; Vicente, C.P.; et al. Low-Level Laser and Adipose-Derived Stem Cells Altered Remodelling Genes Expression and Improved Collagen Reorganization during Tendon Repair. Cell Prolif. 2019, e12580. [CrossRef]

65. Mordon, S.; Capon, A.; Fournier, N.; Iarmarcovai, G. Lasers Thermiques et Cicatrisation Cutanée. Médecine/Sciences 2010, 26, 89-94. [CrossRef] [PubMed]

66. Vitenberga, Z.; Pilmane, M. Age-Related Lung Tissue Remodeling Due to the Local Distribution of MMP-2, TIMP-2, TGF- $\beta$ and Hsp70. Biotech. Histochem. 2018, 93, 239-248. [CrossRef] [PubMed]

67. Nagata, K. HSP47 as a Collagen-Specific Molecular Chaperone: Function and Expression in Normal Mouse Development. Semin. Cell Dev. Biol. 2003, 14, 275-282. [CrossRef] [PubMed]

68. DeBruler, D.M.; Blackstone, B.N.; Baumann, M.E.; McFarland, K.L.; Wulff, B.C.; Wilgus, T.A.; Bailey, J.K.; Supp, D.M.; Powell, H.M. Inflammatory Responses, Matrix Remodeling, and Re-Epithelialization after Fractional CO 2 Laser Treatment of Scars. Lasers Surg. Med. 2017, 49, 675-685. [CrossRef] [PubMed]

69. Nesi-Reis, V.; Lera-Nonose, D.S.S.L.; Oyama, J.; Silva-Lalucci, M.P.P.; Demarchi, I.G.; Aristides, S.M.A.; Teixeira, J.J.V.; Silveira, T.G.V.; Lonardoni, M.V.C. Contribution of Photodynamic Therapy in Wound Healing: A Systematic Review. Photodiagnosis Photodyn. Ther. 2018, 21, 294-305. [CrossRef] 
70. Fortuna, T.; Gonzalez, A.C.; Sá, M.F.; Andrade, Z.; de A Andrade, Z.; Reis, S.R.A.; Medrado, A.R.A.P. Effect of $670 \mathrm{Nm}$ Laser Photobiomodulation on Vascular Density and Fibroplasia in Late Stages of Tissue Repair. Int. Wound J. 2018, 15, 274-282. [CrossRef]

71. White, R.A.; Kopchok, G.E.; Donayre, C.E.; Peng, S.-K.; Fujitani, R.M.; White, G.H.; Uitto, J. Mechanism of Tissue Fusion in Argon Laser-Welded Vein-Artery Anastomoses. Lasers Surg. Med. 1988, 8, 83-89. [CrossRef] [PubMed]

72. Pabittei, D.R.; Heger, M.; Simonet, M.; van Tuijl, S.; van der Wal, A.C.; Beek, J.F.; Balm, R.; de Mol, B.A. Biodegradable Polymer Scaffold, Semi-Solid Solder, and Single-Spot Lasing for Increasing Solder-Tissue Bonding in Suture-Free Laser-Assisted Vascular Repair. J. Tissue Eng. Regen. Med. 2012, 6, 803-812. [CrossRef]

73. Menovsky, T.; Beek, J.F.; Thomsen, S.L. Laser(-Assisted) Nerve Repair. A Review. Neurosurg. Rev. 1995, 18, 225-235. [CrossRef]

74. Fankell, D.P.; Kramer, E.; Cezo, J.; Taylor, K.D.; Ferguson, V.L.; Rentschler, M.E. A Novel Parameter for Predicting Arterial Fusion and Cutting in Finite Element Models. Ann. Biomed. Eng. 2016, 44, 3295-3306. [CrossRef]

75. Leclère, F.M.; Vogt, P.; Schoofs, M.; Delattre, M.; Mordon, S. Current Laser Applications in Reconstructive Microsurgery: A Review of the Literature. J. Cosmet. Laser Ther. 2016, 18, 130-133. [CrossRef]

76. Stewart, R.B.; Bass, L.S.; Thompson, J.K.; Nikoi, N.D.; Becker, G.; Kung, R.T.V. Improved Microvessel Repair: Laser Welding with an Anti-Thrombotic Solder. Lasers Surg. Med. 2002, 31, 36-40. [CrossRef]

77. Bogni, S.; Stumpp, O.; Reinert, M.; Frenz, M. Thermal Model for Optimization of Vascular Laser Tissue Soldering. J. Biophotonics 2010, 3, 284-295. [CrossRef]

78. Hiebl, B.; Ascher, L.; Luetzow, K.; Kratz, K.; Gruber, C.; Mrowietz, C.; Nehring, M.E.; Lendlein, A.; Franke, R.P.; Jung, F. Albumin Solder Covalently Bound to a Polymer Membrane: New Approach to Improve Binding Strength in Laser Tissue Soldering in-Vitro. Clin. Hemorheol. Microcirc. 2018, 69, 317-326. [CrossRef] [PubMed]

79. Tünnermann, A. High-Power Cw Fiber Lasers-Present and Future. Laser Tech. J. 2005, 2, 54-56. [CrossRef]

80. Zervas, M.N.; Codemard, C.A. High Power Fiber Lasers: A Review. IEEE J. Sel. Top. Quantum Electron. 2014, 20, 219-241. [CrossRef]

81. Gursel, A.T. Fiber Lasers and Their Medical Applications. In Optical Amplifiers—A Few Different Dimensions; IntechOpen: London, UK, 2018; Volume I, p. 13. [CrossRef]

82. Pierce, M.C.; Jackson, S.D.; Golding, P.S.; Dickinson, B.; Dickinson, M.R.; King, T.A.; Sloan, P. Development and Application of Fiber Lasers for Medical Applications. Proc. SPIE 2001, 4253, 144-154. [CrossRef]

83. Ganguly, M.; Miller, S.; Mitra, K. Model Development and Experimental Validation for Analyzing Initial Transients of Irradiation of Tissues during Thermal Therapy Using Short Pulse Lasers. Lasers Surg. Med. 2015, 47, 711-722. [CrossRef] [PubMed]

84. Fornaini, C.; Merigo, E.; Poli, F.; Cavatorta, C.; Rocca, J.-P.; Selleri, S.; Cucinotta, A. Use of 1070 Nm Fiber Lasers in Oral Surgery: Preliminary Ex Vivo Study with FBG Temperature Monitoring. Laser Ther. 2017, 26, 311-318. [CrossRef]

85. Aaltonen, I.E.; Wahlström, M. Envisioning Robotic Surgery: Surgeons' Needs and Views on Interacting with Future Technologies and Interfaces. Int. J. Med. Robot. Comput. Assist. Surg. 2018, 14, e1941. [CrossRef] [PubMed]

86. Balkhy, H.H.; Lewis, C.T.P.; Kitahara, H. Robot-Assisted Aortic Valve Surgery: State of the Art and Challenges for the Future. Int. J. Med. Robot. Comput. Assist. Surg. 2018, 14, 1-6. [CrossRef] [PubMed]

87. Namdarian, B.; Dasgupta, P. What Robot for Tomorrow and What Improvement Can We Expect? Curr. Opin. Urol. 2018, 28, 1. [CrossRef] [PubMed]

88. He, W.; Frueh, J.; Hu, N.; Liu, L.; Gai, M.; He, Q. Guidable Thermophoretic Janus Micromotors Containing Gold Nanocolorifiers for Infrared Laser Assisted Tissue Welding. Adv. Sci. 2016, 3, 1600206. [CrossRef] [PubMed]

89. Urie, R.; Guo, C.; Ghosh, D.; Thelakkaden, M.; Wong, V.; Lee, J.K.; Kilbourne, J.; Yarger, J.; Rege, K. Rapid Soft Tissue Approximation and Repair Using Laser-Activated Silk Nanosealants. Adv. Funct. Mater. 2018, 28, 1802874. [CrossRef]

(C) 2019 by the authors. Licensee MDPI, Basel, Switzerland. This article is an open access article distributed under the terms and conditions of the Creative Commons Attribution (CC BY) license (http://creativecommons.org/licenses/by/4.0/). 